\title{
Analisis Komparasi Kinerja Keuangan pada PT. Bank Negara Indonesia (Persero) Tbk dan PT. Panin Bank Periode 2014-2018
}

\author{
Greyti S. Y. Pongoh \\ William A. Areros \\ Joanne $V$. Mangindaan \\ Program Pascasarjana Universitas Sam Ratulangi
}

\begin{abstract}
In measuring the soundness of the bank, Bank Indonesia uses the financial ratio of the CAMELS model (Bank Indonesia Regulation No. 6/10 / PBI / 2004) concerning the Commercial Bank Soundness Rating System. The purpose of this research is to find out the significant differences in financial performance between PT. BNI, Tbk with PaninBank and the dominant variable as a differentiator of significant financial performance between PT. BNI, Tbk with PaninBank. The data analysis method used in this study is two different test independent sample. The results showed that of the 5 variables, there were only two variables that were not statistically different, namely Capital Adequacy Ratio (CAR) (X1) and Loan to Deposit Ratio (LDR) (X5) while the different variables were Return On Risked Asset (RORA) (X2), Net Profit Margin (NPM) (X3) and Return On Assets (ROA) (X4)
\end{abstract}

Keywords: CAMELS, CAR, RORA, NPM, ROA, LDR

\section{PENDAHULUAN}

Usaha industri perbankan memegang peranan penting dalam mendorong pertumbuhan perekonomian suatu negara. Sejalan dengan perkembangan ekonomi maka peran bank sebagai tiang penyanggah yang mendorong peningkatan ekonomi nampak dalam jangkauan usahanya yang semakin luas dan merambat keseluruh lapisan masyarakat sebagai mitra usaha yang menghimpun dan menyalurkan dana dari masyarakat secara menyeluruh. Dalam kegiatan usahanya yang menghimpun dana dari masyarakat dalam bentuk tabungan dan menyalurkan kredit dan jasa-jasa dalam lalu lintas pembayaran serta peredaran uang telah mengalami perkembangan yang pesat, diiringi pula dengan peningkatan kwalitas manajemen dan mutu layanan yang maksimal untuk memelihara dan meningkatkan kepercayaan masyarakat sebagai pengguna jasa yang sempat mengalami kemerosotan pada satu dasawarsa lalu.

Perkembangan perbankan nasional dipengaruhi oleh hal-hal antara lain, persaingan antar bank semakin kuat dalam rangka memberikan pelayanan yang terbaik 
kepada masyarakat, kebijakan moneter yang cenderung ketat, kebijakan suku bunga yang kondusif dari Bank Indonesia, lonjakan inflasi sebagai dampak kenaikan harga komoditi strategis termasuk BBM. Kebijakan ekonomi pemerintah di sektor industri, perdagangan dan jasa juga memberikan kontribusi bagi perkembangan perbankan.

Selain itu tingkat kepercayaan masyarakat terhadap perbankan juga terus meningkat hal ini ditandai dengan peningkatan dana masyarakat ke sektor perbankan (Surifah, 2002). Produk dan jasa perbankan yang ditawarkan kepada masyarakat juga semakin banyak pilihan, sehingga persaingan perbankan makin ketat dan membutuhkan kualitas pelayanan maksimal yang dapat memenuhi keinginan masyarakat penguna jasa.

Program restrukturisasi perbankan yang dicanangkan sejak tahun 1998, telah menunjukkan hasil yang positif. Kondisi kesehatan perbankan mulai baik, hal itu terlihat dari menguatnya struktur permodalan, menurunnya jumlah kredit bermasalah dan meningkatnya profitabilitas perbankan pada umumnya (Rahmawaty, 2008)

Sebagai lembaga keuangan, bankbank di Indonesia yang sedang mengalami pertumbuhan, berusaha untuk dapat memberikan hasil yang terbaik demi kelangsungan usahanya. Salah satunya yaitu dengan menjadi bank yang terbuka untuk publik, dimana segala aspek finansialnya menjadi lebih transparan karena sistem informasi keuangannya menjadi kebutuhan publik sebagai nasabah maupun calon nasabah dengan menggunakan analisis ratio keuangan dalam mengukur kinerja keuangan perbankan.

Kinerja Keuangan merupakan ukuran yang menggambarkan kondisi keuangan, apakah kondisi baik atau tidak baik. (Arthavidya, 2004 : 487). Pengukuran kinerja keuangan lazim dilakukan oleh setiap perusahaan publik secara berkala untuk mengetahui apakah perusahaan telah mencapai tujuan-tujuannya, khususnya dibidang financial. Konsep pentingnya perbandingan kinerja keuangan antar suatu institusi dalam konteks benchmarking dikemukakan oleh Pointon (2005),

this seem to be an appropriate starting point in the determination of $a$ benchmark for corporate financial performance. $\quad . . . \quad A$ sectoral benchmarking group analysis will deal with adjustments for differences in corporate gearing, asset utilization, growth, firm size and intellectual capital.

Argument ini menyatakan bahwa konsep perbandingan (benchmarking) bagi kinerja keuangan perusahaan penting untuk 
dianalisis. Selanjutnya dikatakan bahwa perbandingan sektoral (analisis kelompok atau industri) tercipta karena adanya perbedaan dalam kesesuaian lingkup bisnis perusahaan, penggunaan asset, pertumbuhan, ukuran perusahaan dan modal intelektual. Pendapat ini sebenarnya juga ingin menjustifikasi bahwa perbedaan dalam penggunaan asset, pertumbuhan, ukuran perusahaan dan modal intelektual akan menyebabkan perbedaan dalam kinerja keuangan perusahaan.

Evaluasi terhadap kinerja bank umum dibutuhkan untuk mengetahui kesehatan dan masa depan bank atau perbankan secara keseluruhan. Evaluasi kinerja bank umum sendiri ada kaitanya dengan resiko usaha yang dihadapi bank umum, resikoresiko usaha tersebut dapat dikelola dengan baik. Evaluasi kinerja bank dapat dilakukan dengan menghitung rasio-rasio finansial untuk mengetahui kondisi bank sehat atau tidak, serta masalah-masalah apa yang diperkirakan akan dihadapi (Manurung, 2004 dalam Lestari 2010).

Tugas Bank Indonesia antara lain mempertahankan dan memelihara sistem yang sehat dan dapat dipercaya dengan tujuan menjaga kondisi perekonomian. Untuk itu Bank Indonesia selaku bank sentral dan pengawas kegiatan perbankan di Indonesia memberikan ketentuan ukuran pernilaian tingkat kesehatan bank. Dalam mengukur tingkat kesehatan bank, Bank Indonesia menggunakan rasio keuangan model CAMELS (Peraturan Bank Indonesia No. 6/10/PBI/2004) tentang Sistem Penilaian Tingkat Kesehatan Bank Umum.

Rasio model CAMELS terdiri dari dari komponen Capital, Asset quality, Management, Earning dan Liquidity. Berdasarkan Peraturan Bank Indonesia No. 6/10/PBI/2004 tentang Sistem Penilaian Tingkat Kesehatan Bank Umum, komponen capital digunakan untuk menilai tingkat kecukupan modal bank dalam mengamankan eksposur risiko posisi dan mengantisipasi eksposur risiko yang akan muncul.

Komponen asset quality digunakan untuk menilai kondisi aset bank, termasuk antisipasi atas risiko gagal bayar dari pembiayaan (credit risk) yang akan muncul. Komponen management digunakan untuk menilai kemampuan manajerial pengurus bank dalam menjalankan usaha sesuai dengan prinsip manajemen umum, kecukupan manajemen risiko dan kepatuhan bank terhadap ketentuan baik yang terkait dengan prinsip kehati-hatian dan komitmen bank kepada Bank Indonesia.

Komponen earnings digunakan untuk menilai kemampuan bank dalam menghasilkan laba. Sedangkan komponen 
liquidity digunakan untuk menilai kemampuan bank dalam memelihara tingkat likuiditas yang memadai termasuk antisipasi atas risiko likuiditas yang akan muncul (Surat Edaran Bank Indonesia No. 9/24/DPbS). Hal inilah yang menjadi dasar empiris pentingnya analisis komparasi kinerja keuangan pada beberapa institusi perbankan.

Dasar pemilihan sampel dalam hal ini PT. BNI,Tbk. dan PaninBank didasari pada konsep keterwakilan dari sisi kepemilikan. PT.BNI, Tbk adalah bank pemerintah nasional, sedangkan PaninBank bersifat bank swasta nasional.

\section{METODE PENELITIAN}

Jenis data dalam penelitian ini adalah data kualitatif merupakan data yang disajikan secara deskriptif atau dalam bentuk uraian antara lain data tentang gambaran umum objek penelitian dalam hal ini PT. Bank Negara Indonesia (Persero), Tbk dan PaninBank, dan data kuantitatif merupakan data yang disajikan dalam bentuk angka-angka seperti laporan keuangan tahun 2014-2018 PT. Bank Negara Indonesia (Persero),Tbk dan PaninBank.

Sumber data yang digunakan dalam penelitian ini adalah data sekunder yang diperoleh dari publikasi resmi yaitu data laporan keuangan PT. Bank Negara
Indonesia (Persero),Tbk dan PaninBank periode tahun 2014, 2015, 2016, 2017 sampai dengan tahun 2018 melalui IDX. Com disamping itu, untuk mendukung analisis hasil penelitian juga dibutuhkan sumber lainnya yaitu dari majalah, jurnal, makalah

Metode yang digunakan dalam pengumpulan data adalah dengan cara dokumentasi yaitu dengan cara mengumpulkan laporan keuangan yang sudah dipublikasikan secara resmi oleh PT. Bank Negara Indonesia (Persero),Tbk, dan PaninBank.

Jenis penelitian ini yaitu kualitatif komparatif adalah penelitian yang menjelaskan hubungan antara variable penelitian dan pengujian hipotesis yang dirumuskan sebelumnya dan bersifat studi komparatif, yaitu penelitian yang dilakukan dengan cara membandingkan kinerja keuangan suatu Bank dengan Bank lainnya.

\section{HASIL PENELITIAN}

1. PT. BNI (Persero) Tbk

PT Bank Negara Indonesia (Persero) Tbk (selanjutnya disebut "BNI" ) pada awalnya didirikan di Indonesia sebagai bank sentral dengan nama "Bank Negara Indonesia" berdasarkan Peraturan Pemerintah Pengganti Undang-Undang No. 2 tahun 1946 tanggal 5 Juli 1946. Selanjutnya, berdasarkan Undang-Undang 
No. 17 tahun 1968, BNI ditetapkan menjadi

"Bank Negara Indonesia 1946", dan statusnya menjadi Bank Umum Milik Negara. Selanjutnya, peran BNI sebagai bank yang diberi mandate untuk memperbaiki ekonomi rakyat dan berpartisipasi dalam pembangunan nasional dikukuhkan oleh UU No. 17 tahun 1968 tentang Bank Negara Indonesia 1946. Berdasarkan Peraturan Pemerintah No. 19 tahun 1992, tanggal 29 April 1992, telah dilakukan penyesuaian bentuk hukum BNI menjadi perusahaan perseroan terbatas (Persero). Penyesuaian bentuk hukum menjadi Persero, dinyatakan dalam Akta No. 131, tanggal 31 Juli 1992, dibuat di hadapan Muhani Salim, S.H., yang telah diumumkan dalam Berita Negara Republik Indonesia No. 73 tanggal 11 September 1992 Tambahan No. 1A.

Pada tahun 1996, BNI sebagai bank BUMN (Badan Usaha Milik Negara) pertama yang menjadi perusahaan publik setelah mencatatkan sahamnya di Bursa Efek Jakarta dan Bursa Efek Surabaya (sekarang BEI). Dalam upaya memperkuat struktur keuangan dan meningkatkan persaingan usaha di dunia perbankan nasional, BNI melakukan sejumlah aksi korporasi, antara lain proses rekapitalisasi oleh Pemerintah di tahun 1999, divestasi saham Pemerintah di tahun 2007, dan penawaran umum saham terbatas di tahun
2010. Untuk memenuhi ketentuan UndangUndang No. 40 Tahun 2007 tanggal 16 Agustus 2007 tentang Perseroan Terbatas, Anggaran Dasar BNI telah dilakukan penyesuaian.

Penyesuaian tersebut dinyatakan dalam Akta No. 46 tanggal 13 Juni 2008 yang dibuat di hadapan Fathiah Helmi, S.H., notaris di Jakarta, berdasarkan keputusan Rapat Umum Pemegang Saham Luar Biasa tanggal 28 Mei 2008 dan telah mendapat persetujuan dari Menteri Hukum dan Hak Asasi Manusia Republik Indonesia, dengan Surat Keputusan No. AHU-AH.01.02-50609 tanggal 12 Agustus 2008 dan telah diumumkan dalam Berita Negara Republik Indonesia No. 103 tanggal 23 Desember 2008 Tambahan No. 29015.

Perubahan Anggaran Dasar BNI dilakukan antara lain tentang penyusunan kembali seluruh Anggaran Dasar sesuai dengan Akta No. 45 tanggal 25 April 2017 oleh Notaris Fathiah Helmi, S.H. telah mendapat persetujuan dari Menteri Hukum dan Hak Asasi Manusia Republik Indonesia, dengan surat keputusan No. AHU-0010821.AH.01.02. Tahun 2017 tanggal 17 Mei 2017.

Perubahan terakhir Anggaran Dasar BNI dilakukan antara lain tentang perubahan anggaran dasar Bank sesuai dengan Akta No. 52 tanggal 22 Mei 2018 oleh Notaris Fathiah Helmi, S.H. telah 
mendapat persetujuan dari Menteri Hukum dan Hak Asasi Manusia Republik Indonesia, dengan surat keputusan No. AHU-0012962.AH.01.02.TAHUN 2018 tanggal 25 Juni 2018.

Saat ini, 60\% saham-saham BNI dimiliki oleh Pemerintah Republik Indonesia, sedangkan $40 \%$ sisanya dimiliki oleh masyarakat, baik individu maupun institusi, domestik dan asing. BNI kini tercatat sebagai bank nasional terbesar ke-4 di Indonesia, dilihat dari total aset, total kredit maupun total dana pihak ketiga.

Untuk memperkuat layanan finansial secara terpadu, BNI didukung oleh sejumlah perusahaan anak, yakni Bank BNI Syariah, BNI Multifinance, BNI Securities, BNI Life Insurance, dan BNI Remittance Ltd. BNI juga menawarkan layanan penyimpanan dana maupun fasilitas pinjaman baik pada segmen korporasi, menengah, maupun kecil. Beberapa produk dan layanan terbaik telah disesuaikan dengan kebutuhan nasabah sejak kecil, remaja, dewasa, hingga pensiun.

\section{PaninBank}

PT Bank Pan Indonesia, Tbk (selanjutnya disebut PaninBank atau Perseroan/Bank) merupakan salah satu bank Komersial dan $\mathrm{Ri}$ tel terbesar di Indonesia. Didirikan pada 1971 dari hasil penggabungan usaha Bank Kemakmuran,
Bank Industri Djaja, serta Bank Industri dan Dagang Indonesia, PaninBank memperoleh izin sebagai bank devisa pada 1972. Selanjutnya pada 1982, PaninBank melakukan penawaran saham perdana sekaligus menjadi bank pertama di Indonesia yang mencatatkan sahamnya di lantai bursa.

Dengan ditopang fondasi fundamental yang kuat, PaninBank mampu melewat berbagai periode sulit dalam perekonomian Indonesia. Pada 1998 saat dilanda krisis ekonomi sebagai dampak resesi ekonomi Asia satu tahun sebelumnya, PaninBank masih bisa bertahan sebagai Bank Kategori “A”. Pada periode-periode setelahnya, PaninBank terus melaju mengembangkan berbagai produk dan layanan di bidang perbankan ritel dan komersial.

PaninBank terus tumbuh menjadi salah satu bank SME terdepan di Indonesia dengan didukung sumber daya manusia (SDM) yang andal. Melalui beragam produk dan layanan di segmen perbankan konsumer, small medium enterprise (SME) dan mikro, komersial, korporat, dan tresuri, PaninBank terus menjaga komitmen untuk tumbuh dengan kompetensi yang telah teruji dalam menciptakan nilai sejalan dengan prinsip kehati-hatian.

PaninBank memiliki jaringan perusahaan yang merata di seluruh 
nusantara. Hingga 2018, kami telah memiliki lebih dari 560 kantor cabang di seluruh Indonesia, serta satu kantor perwakilan di Singapura. Pelayanan prima PaninBank juga didukung dengan perbankan Digital, Mobile Banking, Internet Banking, Biznet Panin, serta lebih dari 960 automatic teller machine (ATM) yang tersebar dari Aceh di ujung barat hingga Papua di pelosok timur Nusantara.

Hingga Per 31 Desember 2018, PaninBank memiliki total aset senilai Rp207,20 triliun. Pada tahun ini, penyaluran kredit juga tumbuh 7,93\% menjadi Rp151,57 triliun sementara simpanan nasabah juga sebesar Rp137,69 triliun.

Dalam perkembangannya hingga saat ini, PaninBank juga terus meningkatka penerapan proses tata kelola perusahaan yang baik, dan secara efektif memanfaatkan teknologi informasi untuk menjawab tuntutan pertumbuhan bisnis dan perkembangan zaman.

\section{PEMBAHASAN}

Pembahasan kedua hipotesa adalah sebagai berikut :

1. Hipotesa 1 ( Perbedaan kinerja keuangan PT. Bank Negara Indonesia (Persero), Tbk. dan PaninBank )

Hasil penelitian menunjukkan bahwa secara statistik dari 5 variabel yang diteliti terdapat 3 variabel berbeda antara
PT. Bank Negara Indonesia (Persero), Tbk. dan PaninBank, yaitu variable Return On Risked Asset (RORA) $\left(\mathrm{X}_{2}\right)$, Net Profit Margin (NPM) $\left(\mathrm{X}_{3}\right)$ dan Return On Assets (ROA) ( $\left.\mathrm{X}_{4}\right)$ sedangkan variabel lainnya tidak ada perbedaan.

Hasil penelitian menunjukkan bahwa secara statistic ada perbedaan kinerja keuangan antara ketiga bank yang diteliti. Hasil penelitian ini mendukung hasil penelitian oleh Linda (2015) tentang Analisis Perbandingan kinerja keuangan PT. Bank BRI Tbk dan PT Bank Cimb Niaga Tbk Periode 2009-2014 .Walaupun tidak semua variabel yang diteliti sama dengan penelitian diatas, namun secara umum menunjukkan bahwa ada kesamaan temuan bahwa kinerja keuangan antar bank berbeda secara signifikan, namun penelitian ini berbeda dengan penelitian Debora (2015) bahwa tidak ada perbedaan kinerja keuangan yang signifikan antara Bank Penelitian ini juga dapat digunakan untuk menjustifikasi bahwa agency theory dari Jensen and Meckling (1976) berlaku jika dilihat dari perbedaan struktur kepemilikan (komposisi kepemilikan). Namun disisi lain, walaupun bank yang diteliti berbeda namun tetap berbentuk struktur kepemilikan yang terkonsentrasi, apakah terkonsentrasi pada pemerintah pusat, maupun swasta. Penelitian ini juga mendukung teori firm size dan resources 
based theory, karena perbedaan dalam ukuran perusahaan dan sumberdaya yang dimiliki, ternyata menyebabkan perbedaan dalam kinerja keuangan pada bank yang diteliti.

2. Hipotesa 2 ( Variabel dominan sebagai pembeda kinerja keuangan PT. Bank Negara Indonesia (Persero), Tbk. dan PaninBank )

Hasil penelitian menunjukkan bahwa secara statistik dari 5 variabel yang diteliti, variabel Return On Risked Asset (RORA) $\left(\mathrm{X}_{2}\right)$ merupakan variabel yang paling dominan sebagai pembeda kinerja keuangan antara PT. Bank Negara Indonesia (Persero), Tbk. dan PaninBank dengan tingkat signifikan terkecil sebesar 0.002 dengan tingkat $\mathrm{F}$ hitung sebesar 0.205. ini berarti bahwa hipotesis ke-2 yang menyatakan bahwa di duga Capital Adequacy Ratio (CAR) $\left(\mathrm{X}_{1}\right)$ adalah Variabel yang dominan sebagai pembeda kinerja keuangan yang signifikan PT. Bank Negara Indonesia (Persero), Tbk. dan PaninBank, ditolak atau tidak terbukti karena tingkat signifikan sebesar 0.147 dengan tingkat $\mathrm{F}$ hitung sebesar 2.456 .

Karakteristik kinerja keuangan secara statistik menunjukkan bahwa PT. Bank Negara Indonesia (Persero), Tbk. dan PaninBank cenderung memiliki perbedaan kinerja keuangan (hanya dua variabel yang tidak berbeda). Hal ini dapat terjadi karena

1. Perbankan adalah salah satu industry yang regulasinya sangat ketat, yang secara berkala dipantau oleh Bank Indonesia. Sehingga mekanisme manajemen dan pengelolaan keuangan bank relative mengikuti standartstandart pengelolaan bank yang dibuat di Bank Indonesia. Jadi ada unsur homogenitas dalam pola pengelolaan manajemen dan keuangan umum (mengikuti konsep API atau arsitektur perbankan Indonesia yang dibuat oleh Bank Indonesia).

2. Bank-Bank yang beroperasi di Indonesia cenderung memiliki pangsa pasar yang sama dan dalam kondisi persaingan yang sangat ketat. Walaupun mereka juga bergerak pada kredit Industri besar. Sehingga pola kebijakan keuangan hampir mirip dengan bank-bank lainnya.

3. Keterbatasan dan Rekomendasi Penelitian

Analisis rasio keuangan sangat membantu untuk mengetahui keadaan keuangan suatu bank. Dengan pendekatan kuantitatif yang digunakan memudahkan orang untuk menbaca angka-angka atau ikhtisar statistik, membandingkan dan menafsirkan. Analisis rasio ini memang sangat sederhana sehingga memudahkan orang untuk melihat 
tren atau kecenderungan bank atau perusahaan dan membuat prediksi dimasa depan, namun demikian analisis rasio keuangan ini juga memiliki keterbatasan.

Keterbatasan dari analisis rasio keuangan ini berkaitan dengan ketersediaan laporan keuangan yang benar, ditambah lagi,permasalahan teknis dalam menghitung rasio keuangan berdasarkan laporan keuangan, pemilihan rasio yang tepat untuk digunakan atau memenuhi kepentingan dan keinginan pemakainya. Analisis rasio keuangan ini juga tidak lepas dari bias dan subjektifitas karena mengandung taksiran dan putusan.

Oleh karena itu dalam menganalisis performance perusahaan khususnya bank, menggunakan analisis rasio keuangan belumlah memadai. Hal ini disebabkan oleh keterbatasan-keterbatasan dari alat analisis ini, sehingga sangat diperlukan alat analisis lain yang dapat membantu mengatasi keterbatasan analisis rasio keuangan ini. Alat yang dapat digunakan untuk mengatasi keterbatasan analisis rasio keuangan dalam mengevaluasi performance suatu perusahaan atau bank adalah indeks kinerja non keuangan.

\section{SIMPULAN}

Kesimpulan yang dapat diambil dari penelitian ini yaitu menerima Hipotesis 1 yang menyatakan di duga terdapat perbedaan kinerja keuangan antara PT. Bank Negara Indonesia (Persero), Tbk. dan PaninBank, menolak Hipotesis 2 yang menyatakan di duga Capital Adequacy Ratio (CAR) $\left(\mathrm{X}_{1}\right)$ adalah Variable yang dominan sebagai pembeda kinerja keuangan yang signifikan antara PT. Bank Negara Indonesia (Persero), Tbk. dan PaninBank, Hasil analisis menunjukkan bahwa dari 5 variabel, hanya ada dua variabel yang secara statistic tidak berbeda yaitu Capital Adequacy Ratio (CAR) $\left(\mathrm{X}_{1}\right)$ dan Loan to Deposit Ratio (LDR) $\left(\mathrm{X}_{5}\right)$ disebabkan tingkat siginifikan $>0.05$ sedangkan variabel berbeda yaitu Return On Risked Asset (RORA) $\left(\mathrm{X}_{2}\right)$, Net Profit Margin (NPM) $\left(\mathrm{X}_{3}\right)$ dan Return On Assets (ROA) $\left(\mathrm{X}_{4}\right)$ disebabkan tingkat signifikan < 0.05

Saran dari penulis berdasarkan penelitian ini yaitu :

1. Dalam menanamkan uangnya di Bank sebaiknya nasabah khususnya dalam lingkup tatanan daerah Sulawesi Utara secara konsisten memperhatikan kinerja keuangan perbankan disamping faktor-faktor lainnya agar nasabah lebih nyaman, aman dan puas dalam menentukan bank yang menjadi pilihan yang tepat untuk menginvestasikan uangnya.

2. Manajemen perbankan harus senantiasa bersikap hati-hati dalam 
menangani bisnisnya dengan tetap berpegang pada efisiensi dan efektifitasnya dalam kinerja keuangan

3. Berdasarkan keterbatasan yang ada maka penelitian ini memberi masukan bagi para peneliti yang berminat dalam bidang ini bahwa disarankan untuk memperhatikan dan mempertimbangkan standar lain diluar analisis ratio keuangan yang dapat diperhitungkan untuk menilai dan mengevaluasi bank secara lebih objektif misalnya budget untuk menilai performance bank pada tahun berjalan, standar ilmiah yang dibuat oleh bank dan menambah jumlah variabel yang digunakan sehingga model yang dihasilkan benar-benar menunjukkan kondisi yang seharusnya.

\section{REFERENSI}

Abdullah M. Faisal, 2005, Manajemen Perbankan (Teknik Analisis Kinerja Keuangan Bank), Edisi Pertama Cetakan Ketiga, Penerbit UMM Press. Malang.

Andayani, Endah, 2005. Analisis Kinerja Keuangan Sebelum dan Sesudah Akuisisi pada Perusahaan Manufaktur yang Tercatat di Bursa Efek Jakarta, Jurnal Ekonomi dan Manajemen Universitas Gajayana, Volume 6, N0.2,347
Anthony N. Robert dan Govindarajan Vijay, 2005. Management Control System, $11^{\text {th }}$ ed, Penerbit Salemba Empat, Jakarta.

Arthavidya, 2004, Analisis Kinerja Keuangan , Edisi Pertama Cetakan Ketiga, Penerbit Salemba Empat. Jakarta

Debora. 2015. Analisis Perbandingan Kinerja Keuangan Dengan Menggunakan Metode CAMEL (Studi pada PT. Bank JATENG dan PT. Bank DKI). Artikel Ilmiah Mahasiswa.

Demsetz, Harold And Kenneth Lehn, 1985, The Structure Of Corporate Ownership, Journal of Political Economy, Vol. 93. No. 6. P.11551177.

And Belen Villalonga, 2001, Ownership Structure And Corporate Performance, Journal of Corporate Finance, 7, P. 209-233.

Dendawijaya, 2007. Manajemen Perbankan, Ghalia Indonesia, Cetakan Kedua, Jakarta

Dunia A. Firdaus, 2005, Ikhtisar Lengkap Pengantar Akuntansi, Penerbit FEUI Jakarta.

Farida, Ilya. (1998) Analisis VariabelVariabel Yang Menentukan Struktur Modal Beberapa Perusahaan Manufaktur di Bursa Efek Jakarta. Tesis Program Pascasarjana, Universitas Brawijaya Malang.

Garrison H. Ray dan Noreen W. Eric, 2004, Akuntansi Manajerial, Penerbit Salemba Empat, Jakarta.

Ghoniyah, Nunung. (1997) Analisis Pengaruh Struktur Modal 
Terhadap Rentabilitas Modal Sendiri dan Laba Per Saham pada Industri Food and Beverage Yang Go Public di Indonesia. Tesis Program Pascasarjana, Uuniversitas Brawijaya

Hanafi M. Mamduh dan Halim Abdul, 2005, Analisa Laporan Keuangan, Penerbit UPP-AMP, Yogyakarta.

Hansen dan Mowen, 2004, Akuntansi Manajemen, Buku I, Penerbit Salemba Empat, Jakarta.

Harnanto, 2004, Akuntansi Keuangan Menengah, Penerbit Liberty, Yogyakarta.

Horngren C. T. Horrison dan W. T. Bamber L.S, 2004, Accounting Edition 5, Precintice-Hall, Int, New Jersey, Penerbit PT. Salemba Empat, Jakarta.

Hastuti, Theresia Dwi. Hubungan Antara Good Corporate Governance dan Struktur Kepemilikan Dengan Kinerja Keuangan (Studi Kasus pada Perusahaan yang listing di Bursa Efek Jakarta). 2005.

Ikatan Akuntan Indonesia, 2004, Standar Akuntansi Keuangan, Penerbit PT. Salemba Empat, Jakarta.

Indriyo, Drs, 1997. Manajemen Keuangan, Penerbit Fakultas Ekonomi Universitas Gajah Mada, Yogyakarta

Jensen, Michael C And William H.Meckling, 1976, Theory Of Firm : Managerial Behavior, Agency Cost, And Ownership Structure, Journal Of Financial Economics, 3, July, P.305-360.
Kamarudin Ahmad, 2005, Akuntansi Manajemen "Dasar-dasar Konsep Biaya dan Pengambilan Keputusan", Buku I, PT. Raja Grafindo Persada, Jakarta.

Kasmir,2000, Bank dan Lembaga Keuangan Lainnya, PT. Raja Grafindo Persada, Jakarta.

Kieso, Weygant, Warfield, 2004, Akuntansi Intermediate, Jilid II, Penerbit Erlangga, Jakarta.

Kuncora Mudrajat, 2003, Metode Riset untuk Bisnis dan Ekonomi, Penerbit Erlangga, Jakarta.

Kusnar, 2004, Bank dan Lembaga Keuangan lainnya, Jilid II, Penerbit PT. Raja Grafindo Persada, Jakarta.

Linda, M. T. 2015. Analisis Perbandingan Kinerja Keuangan Periode Tahun 2009-2014 (Studi pada PT. Bank BRI Tbk dan Bank CIMB Niaga Tbk). Artikel Ilmiah Mahasiswa.

Marentek. 2013. Analisis Kinerja Keuangan Antara Bank Negara Indonesia (BNI) dan Bank Mandiri Menggunakan Metode CAMEL. Artikel Ilmiah Mahasiswa.

Meliangan. 2014. Analisis Perbandingan Kinerja Keuangan Bank BCA dan Bank CIMB Niaga. Artikel Ilmiah Mahasiwa

Lee, F. Cheng. (1985) Financial Analisis \& Planing Theory \& Aplication. Edition Wesley. Publising Company USA

Lestari. 2010. Analisis kinerja Bank Umum di Indonesia dan Malaysia (Studi Komparatif tahun 2007-2009). Skripsi. Malang. Universitas Negeri Malang. 
Mangkuprawira Sjafri, 2004, Manajemen Sumber Daya Manusia Strategik, Penerbit Ghalia Indonesia, Jakarta.

Mardiasmo, 2004, Akuntansi Sektor Publik, Andi, Yogyakarta.

Matilla, Ahlqvist, 2001. Analisis Laporan Keuangan, Penerbit Erlangga, Jakarta

Mulyadi, 2004, Akuntansi Manajemen, Penerbit Salemba Empat, Jakarta.

Penrose, E. 1959. The theory of the growth of the firm. New York: Wiley.

Pilok Reni, 2005. Analisis Kinerja Keuangan pada Bank Mega, Tbk. Ekonomi Unsrat Manado

Poiton John, 2005, Benchmarking financial performance, working paper, university of Plymouth, pp.1-18.

Rahmawati, Insa.2008 Analisis Komparasi Kinerja Keuangan Antara PT Bank Syariah, Bank Mandiri dan PT Bank Rakyat Indonesia Periode 1999-2001.

Rajan, G. Raghuran and Zingales, Luigi. (1995) What Do We Know About Capital Structure? Some Evidence From International Data, Jurnal of Finance, Vol.50, No.5.

Ratag,Leidy.S.B, Analisis Kinerja Keuangan Pada PT. Nindya Karya Cabang Papua Sebelum dan Sesudah Krisis Moneter, FISIP Unsrat Manado

Sandiman Jumadi, 2006, Penerapan Economic Value Added (EVA) sebagai Alat Ukur Kinerja Keuangan pada PT. Bank Sulut, Skripsi S1 Fakultas Ekonomi Universitas Sam
Ratulangi Manado. Tidak dipublikasikan.

Saragih D. Ferdinand, 2005. Dasar-dasar Keuangan Bisnis Teori dan Aplikasi, PT. Alex Media Komputindo, Jakarta

Sartono, Agus. (1996) Manajemen Keuangan. Edisi ketiga, Penerbit BPFE, Yogyakarta.

Sawir Agnes, 2003, Analisis Kinerja Keuangan dan Perencanaan Keuangan Perusahaan,__PT. Gramedia Pustaka Utama, Jakarta.

Sonhiji, 2005, Pengantar Akuntansi, Edisi I, Penerbit Bayu Media Publishing, Jakarta.

Surifah. 2002. Kinerja Keuangan Perbankan Swasta Nasional Indonesia Sebelum dan Setelah Krisis Ekonomi.

Syamsuddin Lukman, 2004, Manajemen Keuangan Perusahaan, Penerbit PT. Raja Grafindo Persada, Jakarta.

Tunggal W. Amin, 2003, Memahami Konsep Economic Value Added (EVA) dan Value Based Management (VAM), Harvarindo, Jakarta.

Umar Husein, 2007, Riset Akuntansi, Penerbit PT. Gramedia Pustaka Utama, Jakarta.

Yusuf Haryono, 2004, Dasar-Dasar Akuntansi, Edisi 6, Penerbit STIE YKPN, Yogyakarta. 